\title{
Microgrids dynamic stability interconnected through low voltage AC network
}

\author{
Vinit Kumar Singh, Ashu Verma, T. S. Bhatti \\ Centre for Energy Studies, Indian Institute of Technology Delhi, Hauz Khas, New Delhi, India
}

\begin{tabular}{l} 
Article Info \\
\hline Article history: \\
Received May 11, 2021 \\
Revised Aug 2, 2021 \\
Accepted Aug 20, 2021 \\
\hline
\end{tabular}

\section{Keywords:}

Biogas system

Low voltage AC line

Microgrid

Photovoltaic system

Renewable energy

Stability study

Wind energy system

\begin{abstract}
Renewable energy based microgrids have main challenges of maintaining its frequency-voltage characteristics and system becomes more complex when they are interconnected. These sources being intermittent in nature need to be supported by other resources like diesel/biogas such that at time of small variation in load or natural sources (wind/solar), power requirement is met through support provided by diesel/biogas-based system. Also, the controller should be fast enough to minimize the changes such that system reaches steady state. In this paper, renewable based rural microgrid consisting of wind, solar and biogas is modeled and interconnected through low voltage $\mathrm{AC}$ (LVAC) line. Also, one of the microgrid modeled is connected to the main grid as well as drawing power from the other microgrid. Control approach have been developed in such a way that whenever there is disturbance in the system due to increase/decrease in load or input to the renewable energy sources the biogas-based system of individual microgrid increases/decreases its generation to support the system requirement. No extra power is drawn either from the LVAC network or main grid as desired. modeling of system and its dynamic Study has been carried out in MATLAB/Simulink.
\end{abstract}

This is an open access article under the CC BY-SA license.

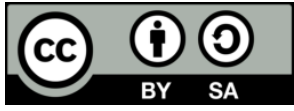

\section{Corresponding Author:}

Vinit Kumar Singh

Centre of Energy Studies

Indian Institute of Technology

Hauz Khas, New Delhi, India

Email: singhvinitk@gamil.com

\section{INTRODUCTION}

Renewable energy generation-based power plants in small and large scale are needed to be installed in India to meet the power requirement and decrease dependency on thermal [1]. In this paper dynamic stability study has been carried for cluster of villages forming rural Microgrid with local load and interconnection with other rural microgrid as well as main grid. Novelty in the paper is modeling based on realistic approach in formation of microgrid based on available renewable energy sources and its control. Such type of microgrid is required in future to minimize long distance transmission, reduce dependency on main grid and to harness renewable energy sources in small scale.

Use of power electronics has made it easier for asynchronous interconnection of microgrid through dc link and back to back convertor and also drawing power from WES/PVS [2]. The control and optimization of a hybrid ac/dc network are still an open problem [3]-[5]. The coordinated control architecture using power electronics devices has made it easier to control the system frequency and voltage [6], [7]. Inverters form critical equipment in control architecture of controlling power from renewables [8]. Many studies have been carried out in active and reactive power control of hybrid power system [9]-[11]. Therefore, generation mix 
of wind-solar-biogas could be developed to provide power to habitants and small-scale industries locally using optimal use of renewable energy resources. Various literature and works have been carried out considering wind turbine with different types of generators and its control. The main goal of any system is to maintain a constant voltage profile and frequency produced by the system and this can be expressed in terms of constant angular velocity of the turbine rotor. Therefore, the angular position of the rotor works as a control signal. PMSG with wind turbine can be designed to generate high voltage at small revolution and high current at faster speeds and also has many advantages [12], [13]. Wind turbine with Induction Generator requires reactive power control which is supplied by capacitor bank or static compensator [14]. PVS dc power output dependents on temperature and solar irradiation. In order to excerpt extreme power from a PV cell at a given temperature and solar irradiance operating conditions, a maximum power point tracking (MPPT) system is essential. The most two common maximum power point tracking algorithms are: perturb and observe (P\&O) and incremental conductance (IC) [15], [16].

Microgrid is energy system which is locally controlled and uses various categories of renewable energy assets (solar, wind, biomass, hydro and ocean), generators (biogas, diesel and gasoline), energy storage systems (batteries, flywheel, fuel cell and thermal), loads (residential and industrial) and control equipment [17]. A microgrid model optimizing local renewable energy resources for on-grid area was investigated for energy cost saving and reduction in $\mathrm{CO}_{2}$ emission [18]. The problem of interconnecting microgrids is major area of concern because being small system, frequency, voltage and phase angle may vary with nominal disturbance. Since the microgrid consist of various generating sources, due to different power sharing capacity the chances of microgrid failure are higher in case of fault or heavy change in load or in drop in renewable energy source [19], [20]. Main cause of collapse is very fast response of inverter-based system and slow response of prime mover based reciprocating engine. In such case controller is designed and tuned in such a way so that effect is nullified very fast. Fractional order proportional integral controller (FOPI) $\left(\mathrm{PI}^{\alpha}\right)$ based controller is one of the solutions. More flexibility was extended in traditional notion of PID controllers with the controller gains define the fractional differential and integrals as design variables [21]-[23]. The fractional-order system can be approximated by many methods [24]. Based on approximation, the FOMCON toolbox was used for creating the fractional-order system [25], [26].

The rest of the paper is organized as follows: Section-2 gives the detail of the system considered for investigation. Section 3 comprises of description regarding modeling of microgrids and its associated line. Section 4 discuss about the simulation of the system and results. Finally, section-5 is the conclusion of the paper under consideration.

\section{SYSTEM CONSIDERED FOR INVESTIGATION}

In the system modeling two clusters viz. MG-1 and MG-2 are considered for stability study. System details with FOPI tuned parameters, low voltage AC (LVAC) line data, MG-1 data and MG-2 data are given in Table 1, Table 2, Table 3 and Table 4. Both the clusters are rated at $1500 \mathrm{~kW}$. It is assumed that the power is flowing from MG-1 to MG-2. MG-1 consists of WES rated at $1000 \mathrm{~kW}$ and biogas generation system (BG1) with synchronous generator rated at $500 \mathrm{~kW}$. Data of BG1 and WES are given in Table 5 and Table 6. MG-1 has local load of $1000 \mathrm{~kW}$ and also transmitting $100 \mathrm{~kW}$ to MG-2 considering loss of $5 \mathrm{~kW}$ through LVAC network i.e total generation of MG-1 is $1105 \mathrm{~kW}$. MG-2 consists of PVS rated at $650 \mathrm{~kW}$, Biogas generation system (BG2) rated at $500 \mathrm{~kW}$ and grid rated at $350 \mathrm{~kW}$. Data of BG2, PVS and grid are given in Table 7, Table 8 and Table 9. LVAC network consists of 3-phase overhead Ariel Bunched cable (ABC). The size of cable considered is $150 \mathrm{~mm}^{2}$ aluminum conductor rated at 415 Volts. The objective of the LVAC network is to supply constant power of $100 \mathrm{~kW}$ to MG-2. Supply from limited grid is considered constant and is supplying to priority loads only. In the limited grid the voltage as well as the angle at that bus is kept constant.

Table 1. FOPI data

\begin{tabular}{ccccccc}
\hline \multirow{2}{*}{ Controller } & \multicolumn{3}{c}{ MG-1 } & \multicolumn{3}{c}{ MG-2 } \\
& $\mathrm{P}\left(\mathrm{K}_{\mathrm{p}}\right)$ & $\mathrm{I}\left(\mathrm{K}_{\mathrm{i}}\right)$ & $\alpha$ & $\mathrm{P}\left(\mathrm{K}_{\mathrm{p}}\right)$ & $\mathrm{I}\left(\mathrm{K}_{\mathrm{i}}\right)$ & $\alpha$ \\
\hline FOPI1 & 6.987 & 2.578 & 0.45 & 2.745 & 4.572 & 0.8 \\
FOPI2 & -6.296 & -8.578 & 0.5 & -1.425 & -7.887 & 0.71 \\
FOPI3 & 1.945 & 10.676 & 0.8 & 10.355 & 2.765 & 0.2 \\
FOPI4 & -2.378 & -5647 & 0.7 & 9.567 & -3097 & 0.9 \\
\hline
\end{tabular}

The MG-1 and MG-2 microgrid has been modeled considering total contract demand $=1725 \mathrm{~kW}$. Maximum differentiated demand at diversity factor of $0.58=1725 * 0.58=1000 \mathrm{~kW}$ (approx.). 
Table 2. LVAC data

\begin{tabular}{cccc}
\hline value & value & value & value \\
\hline $\mathrm{R}=0.562 \mathrm{pu}$ & $\mathrm{X}_{=}=0.268 \mathrm{pu}$ & $\mathrm{K}_{1 \mathrm{ac}}=1.758$ & $\mathrm{~K}_{2 \mathrm{ac}}=-1.137$ \\
$\mathrm{~K}_{3 \mathrm{ac}}=1.132$ & $\mathrm{~K}_{4 \mathrm{ac}}=0.252$ & $\mathrm{~K}_{5 \mathrm{ac}}=-1.132$ & $\mathrm{~K}_{6 \mathrm{ac}}=-1.137$ \\
$\mathrm{~K}_{7 \mathrm{ac}}=1.514$ & $\mathrm{~K}_{8 \mathrm{ac}}=-1.381$ & $\mathrm{~K}_{9 \mathrm{ac}}=0.531$ & $\mathrm{~K}_{10 \mathrm{ac}}=0.531$ \\
$\mathrm{~K}_{11 \mathrm{ac}}=-1.733$ & $\mathrm{~K}_{12 \mathrm{ac}}=-1.514$ & & \\
\hline
\end{tabular}

Table 3. Generation parameters of MG-1

\begin{tabular}{lccc}
\hline Sources & Rated Capacity $(\mathrm{kW})$ & Generation $(\mathrm{kW})$ & Participation Factor \\
\hline Biogas & 500 & 350 & 0.2333 \\
WES & 1000 & 755 & 0.5020 \\
Total & 1500 & 1105 & \\
\hline
\end{tabular}

$\mathrm{D}_{\mathrm{FS}}=\frac{\partial P_{L}}{\partial \mathrm{f}}=\frac{P_{L}}{P_{R^{*}} * f}=0.01333 \mathrm{pu} \mathrm{kW} / \mathrm{Hz}$.

$\mathrm{K}_{\mathrm{FS} 1}=1 / D_{F S 1}=75 \mathrm{~Hz} / \mathrm{pu} \mathrm{kW}$.

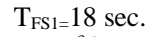

$\mathrm{D}_{\mathrm{VS} 1}=\frac{\partial Q_{L}}{\partial \mathrm{V}}=\frac{Q_{L}}{Q_{R^{* V}}}=\frac{P_{L}}{P_{R^{* V}}}=0.6777 \mathrm{pu} \mathrm{kVAR} / \mathrm{pu} \mathrm{kV}$

$\mathrm{K}_{\mathrm{VS} 1}=1 / D_{V S 1}=1.5 \mathrm{pu} \mathrm{kV} / \mathrm{pu} \mathrm{kVAR}$.

$\mathrm{T}_{\mathrm{VS} 1}=0.004$ sec. $\mathrm{pf}=0.866$, PL $1=0.6667 \mathrm{pu}$

Table 4. Generation parameters of MG-2

\begin{tabular}{lccc}
\hline \multicolumn{1}{c}{ Sources } & Rated Capacity $(\mathrm{kW})$ & Generation $(\mathrm{kW})$ & Participation Factor \\
\hline Grid & 350 & 300 & 0.2 \\
Biogas & 500 & 300 & 0.2 \\
$\mathrm{PV}$ & 650 & 300 & 0.2 \\
Total & 1500 & $900+100($ Line $)$ & \\
\hline $\mathrm{D}_{\mathrm{FS} 2}=\frac{\partial P_{L}}{\partial \mathrm{f}}=\frac{P_{L}}{P_{R^{*}}}=0.0133 \mathrm{pu} \mathrm{kW} / \mathrm{Hz}$. & & \\
$\mathrm{K}_{\mathrm{FS} 2=1 / D_{F S 2}}=75 \mathrm{~Hz} / \mathrm{pu} \mathrm{kW}$. & \\
$\mathrm{T}_{\mathrm{FS} 2=6 \mathrm{sec} .}$ & & \\
$\mathrm{D}_{\mathrm{V} 2=} \frac{\partial Q_{L}}{\partial \mathrm{V}}=\frac{Q_{L}}{Q_{R^{* V}}}=\frac{P_{L}}{P_{R^{* V}}}=0.6667 \mathrm{pu} \mathrm{kVAR} / \mathrm{pu} \mathrm{kV}$. \\
$\mathrm{K}_{\mathrm{V} 2=1 / D_{V S 2}=1.5 \mathrm{pu} \mathrm{kV} / \mathrm{pu} \mathrm{kVAR} .}$ \\
$\mathrm{T}_{\mathrm{V} 2=0.004 \text { sec. } \mathrm{pf}=0.866, \mathrm{P}_{\mathrm{L} 2}=0.6667 \mathrm{pu}}$
\end{tabular}

Table 5. Biogas (BG1) data

\begin{tabular}{cc}
\hline value & value \\
\hline $\mathrm{P}_{\mathrm{BG} 1}=0.2333 \mathrm{pu} \mathrm{kW}$ & $\mathrm{Q}_{\mathrm{BG} 1}=0.1346 \mathrm{pu} \mathrm{kVAR}$ \\
$\mathrm{X}_{\mathrm{d}}=1 \mathrm{pu}$ & $\mathrm{X}_{\mathrm{d}}{ }^{\prime}=0.15 \mathrm{pu}$ \\
$\mathrm{T}_{\mathrm{BG} 1}=0.01 \mathrm{sec}$ & $\mathrm{T}_{\mathrm{BG} 2}=0.02 \mathrm{sec}$ \\
$\mathrm{T}_{\mathrm{BG} 5}=0.014 \mathrm{sec}$ & $\mathrm{T}_{\mathrm{BG} 6}=0.04 \mathrm{sec}$ \\
$\mathrm{T}_{\mathrm{BG} 7}=0.036 \mathrm{sec}$ & $\mathrm{K}_{\mathrm{AB}}=200$ \\
$\mathrm{~T}_{\mathrm{EB}}=2.0 \mathrm{sec}$ & $\mathrm{K}_{\mathrm{FB}}=0.5$ \\
$\mathrm{~T}_{\mathrm{AB}}=0.05 \mathrm{sec}$ & $\mathrm{K}_{\mathrm{EB}}=1$ \\
$\mathrm{~T}_{\mathrm{FB}}=1.0 \mathrm{sec}$ & $\mathrm{K}_{1 \mathrm{BG} 1}=0.15$ \\
$\mathrm{~K}_{2 \mathrm{BG} 1}=0.831$ & $\mathrm{~K}_{3 \mathrm{BG} 1}=6.515$ \\
$\mathrm{~K}_{4 \mathrm{BG} 1}=-6.844$ & $\mathrm{~T}_{\mathrm{d} 0}{ }^{6}=5.0 \mathrm{sec}$ \\
$\mathrm{T}_{\mathrm{GBG} 1}=0.75 \mathrm{sec}$ & \\
\hline
\end{tabular}

Table 7. Biogas (BG2) data

\begin{tabular}{cc}
\hline value & value \\
\hline $\mathrm{P}_{\mathrm{BG} 1}=0.2 \mathrm{pu} \mathrm{kW}$ & $\mathrm{Q}_{\mathrm{B} \mathrm{G} 1}=0.1154 \mathrm{pu} \mathrm{kVAR}$ \\
$\mathrm{X}_{\mathrm{d}}=1 \mathrm{pu}$ & $\mathrm{X}_{\mathrm{d}}{ }^{\prime}=0.15 \mathrm{pu}$ \\
$\mathrm{T}_{\mathrm{BG} 1}=0.01 \mathrm{sec}$ & $\mathrm{T}_{\mathrm{BG} 2}=0.02 \mathrm{sec}$ \\
$\mathrm{T}_{\mathrm{BG} 5}=0.014 \mathrm{sec}$ & $\mathrm{T}_{\mathrm{BG} 6}=0.04 \mathrm{sec}$ \\
$\mathrm{T}_{\mathrm{BG} 7}=0.036 \mathrm{sec}$ & $\mathrm{K}_{\mathrm{AB}}=200$ \\
$\mathrm{~T}_{\mathrm{EB}}=2.0 \mathrm{sec}$ & $\mathrm{K}_{\mathrm{FB}}=0.5$ \\
$\mathrm{~T}_{\mathrm{AB}}=0.05 \mathrm{sec}$ & $\mathrm{K}_{\mathrm{EB}}=1$ \\
$\mathrm{~T}_{\mathrm{FB}}=1.0 \mathrm{sec}$ & $\mathrm{K}_{1 \mathrm{BG} 1}=0.15$ \\
$\mathrm{~K}_{2 \mathrm{BG} 1}=0.831$ & $\mathrm{~K}_{3 \mathrm{BG} 1}=6.515$ \\
$\mathrm{~K}_{4 \mathrm{BG} 1}=-6.844$ & $\mathrm{~T}_{\mathrm{d} 0}{ }^{\circ}=5.0 \mathrm{sec}$ \\
$\mathrm{T}_{\mathrm{GBG} 1}=0.75 \mathrm{sec}$ & \\
\hline
\end{tabular}

Table 6. WES data

\begin{tabular}{cc}
\hline value & value \\
\hline $\mathrm{P}_{\mathrm{WES}}=0.503 \mathrm{pu}$ & $\mathrm{Q}_{\mathrm{WES}}=0.290 \mathrm{pu}$ \\
$\mathrm{X}_{\mathrm{TINV}}=0.5 \mathrm{pu}$ & $\mathrm{T}_{\mathrm{d}}=0.005 \mathrm{sec}$ \\
$\mathrm{K}_{\mathrm{WES} 1}=2.265$ & $\mathrm{~K}_{\mathrm{WES} 2}=2.265$ \\
$\mathrm{~K}_{\mathrm{WES} 3}=0.433$ & $\mathrm{~K}_{\mathrm{WES} 4}=0.5$ \\
$\mathrm{~K}_{\mathrm{WES} 5}=-0.5$ & $\mathrm{~K}_{\mathrm{WES} 6}=-0.5$ \\
$\mathrm{~K}_{\mathrm{WES} 7}=1.953$ & $\mathrm{~K}_{\mathrm{WES} 8}=-1.735$ \\
\hline
\end{tabular}

Table 8. PVS data

\begin{tabular}{cc}
\hline value & value \\
\hline $\mathrm{P}_{\mathrm{PV} 1}=0.2 \mathrm{pu}$ & $\mathrm{Q}_{\mathrm{PV} 1}=0.1154 \mathrm{pu}$ \\
$\mathrm{X}_{\mathrm{TPV}}=0.8 \mathrm{pu}$ & $\mathrm{T}_{\mathrm{PV} 1}=0.005 \mathrm{sec}$ \\
$\mathrm{K}_{\mathrm{PV} 1}=1.467$ & $\mathrm{~K}_{\mathrm{PV} 2}=1.467$ \\
$\mathrm{~K}_{\mathrm{PV} 3}=0.169$ & $\mathrm{~K}_{\mathrm{PV} 4}=0.2$ \\
$\mathrm{~K}_{\mathrm{PV} 5}=-0.2$ & $\mathrm{~K}_{\mathrm{PV} 6}=-0.2$ \\
$\mathrm{~K}_{\mathrm{PV} 7}=1.238$ & $\mathrm{~K}_{\mathrm{PV} 8}=-1.03$ \\
\hline
\end{tabular}

Table 9. Grid data

\begin{tabular}{cc}
\hline value & value \\
\hline $\mathrm{P}_{\mathrm{G}}=0.2 \mathrm{pu}$ & $\mathrm{Q}_{\mathrm{G}}=0.1154 \mathrm{pu}$ \\
$\mathrm{K}_{1 \mathrm{G}}=-2.875$ & $\mathrm{~K}_{2 \mathrm{G}}=0.2$ \\
$\mathrm{~K}_{3 \mathrm{G}}=0.2$ & $\mathrm{~K}_{4 \mathrm{G}}=-2.681$ \\
\hline
\end{tabular}

Int J Appl Power Eng, Vol. 10, No. 4, December 2021: 326 - 336 


\section{MODELING OF INTERCONNECTED MICROGRIDS WITH LVAC NETWORK}

At steady state, the power transferred through the interconnection remains same at all conditions. Any change in demand or generation is taken care locally by the respective microgrid system. The system line diagram is shown in Figure 1.

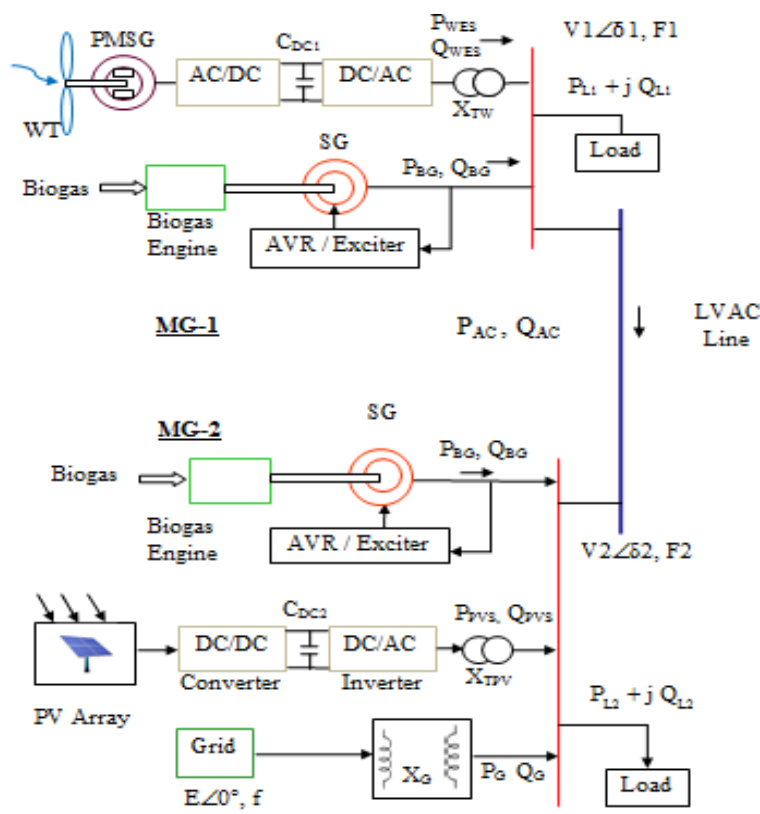

Figure 1. Line diagram of MG-1 and MG-2 connected through AC line

The power balance equations are given as (1) (2) (3) and (4).

$$
\begin{aligned}
& \text { PBG1+PWES=PL1+Ps } \\
& \text { QBG1+QWES=QL1+QS } \\
& \text { PBG2+PPVS+PG+Pr =PL2 } \\
& \text { QBG2+QPVS+QG+Qr=PL2 }
\end{aligned}
$$

For small change in power (1) (2) (3) and (4) can be rewritten as (5) (6) (7) and (8).

$$
\begin{aligned}
& \Delta \mathrm{PBG} 1+\Delta \mathrm{PWES}=\Delta \mathrm{PL} 1+\Delta \mathrm{Ps} \\
& \Delta \mathrm{QBG} 1+\Delta \mathrm{QWES}=\Delta \mathrm{QL} 1+\Delta \mathrm{Qs} \\
& \Delta \mathrm{PBG} 2+\Delta \mathrm{PPVS}+\Delta \mathrm{Pr}=\Delta \mathrm{PL} 2 \\
& \Delta \mathrm{QBG} 2+\Delta \mathrm{QPVS}+\Delta \mathrm{QG}-\Delta \mathrm{Qr}=\Delta \mathrm{PL} 2
\end{aligned}
$$

The change in active power generated and absorbed by load will result in the system frequency deviance which can be expressed in s domain as (9) and (10).

$$
\begin{aligned}
& \Delta \mathrm{F} 1(\mathrm{~s})=\frac{\mathrm{Kp} 1}{1+s T p 1}[\Delta \mathrm{PBG} 1(\mathrm{~s})+\Delta \mathrm{PWES}(\mathrm{s})-\Delta \mathrm{Ps}(\mathrm{s})-\Delta \mathrm{PL} 1(\mathrm{~s})] \\
& \Delta \mathrm{F} 2(\mathrm{~s})=\frac{\mathrm{Kp} 2}{1+s T p 2}[\Delta \mathrm{PBG} 2(\mathrm{~s})+\Delta \mathrm{PPVS}(\mathrm{s})+\Delta \mathrm{PG}(\mathrm{s})+\Delta \operatorname{Pr}(\mathrm{s})-\Delta \mathrm{PL} 2(\mathrm{~s})]
\end{aligned}
$$

Similarly, for reactive power the equation can be written as (11) and (12). 


$$
\begin{aligned}
& \Delta \mathrm{V} 1(\mathrm{~s})=\frac{\mathrm{Kv} 1}{1+s T v 1}[\Delta \mathrm{QBG} 1(\mathrm{~s})+\Delta \mathrm{QWES}(\mathrm{s})-\Delta \mathrm{QS}(\mathrm{s})-\Delta \mathrm{QL} 1(\mathrm{~s})] \\
& \Delta \mathrm{V} 2(\mathrm{~s})=\frac{\mathrm{Kv} 2}{1+s T v 2}[\Delta \mathrm{QBG} 2(\mathrm{~s})+\Delta \mathrm{QPVS}(\mathrm{s})+\Delta \mathrm{QG}(\mathrm{s})+\Delta \mathrm{Qr}(\mathrm{s})-\Delta \mathrm{QL} 2(\mathrm{~s})]
\end{aligned}
$$

$\mathrm{P}_{\mathrm{BG}}, \mathrm{P}_{\mathrm{WES}}, \mathrm{P}_{\mathrm{PVS}}, \mathrm{P}_{\mathrm{G}}, \mathrm{P}_{\mathrm{S}}, \mathrm{P}_{\mathrm{r}}$ and $\mathrm{P}_{\mathrm{L}}$ are active power of biogas, wind, solar, grid, line sending end power, line receiving end power and load. $\mathrm{Q}_{\mathrm{BG}}, \mathrm{Q}_{\mathrm{WES}}, \mathrm{Q}_{\mathrm{PVS}}, \mathrm{Q}_{\mathrm{G}}, \mathrm{Q}_{\mathrm{S}}, \mathrm{Q}_{\mathrm{r}}$ and $\mathrm{Q}_{\mathrm{L}}$ are reactive power biogas, wind, solar, grid, line sending end power, line receiving end power and load. $\Delta \mathrm{F} 1$ and $\Delta \mathrm{F} 2$ are change in frequency of MG-1 and MG-2 respectively. $\mathrm{K}_{\mathrm{p}}, \mathrm{T}_{\mathrm{p}}, \mathrm{K}_{\mathrm{v}}$ and $\mathrm{T}_{\mathrm{v}}$ are power system gain and time constant for change in active power and reactive power.

\subsection{Modeling of WES and PVS connected inverter}

The WES includes turbine together with PMSG which generates power having frequency and voltage variable in nature depending upon wind speed. The generator side AC-DC power electronics converter transmits the power of the PMSG to the load side DC-AC converter through a coupling capacitor in between the converters. The PVS comprises Photovoltaic Cell coupled with Buck Boost Converter. The PV side DC-DC converter transmits the power of the PV cell to the load side DC-AC converter through a coupling capacitor in between. The coupling capacitor helps in maintaining constant voltage across the convertors. Small signal model of the WES and PVS is established using power output equations from the Inverter model given as (13) and (14).

$$
\begin{aligned}
& P I N V=\frac{V \operatorname{inv} V \operatorname{Sin}(\delta+\theta)}{X T I N V} \\
& Q I N V=\frac{V \operatorname{inv} V \operatorname{Cos}(\delta+\theta)-V}{X T I N V}
\end{aligned}
$$

For small variation in the output power of the Inverter (13) and (14) can be written as (15) and (16)

$$
\begin{aligned}
& \Delta \mathrm{P}_{\mathrm{INV}}(\mathrm{s})=\mathrm{K}_{\text {inv1 }} \Delta \delta(\mathrm{s})+\mathrm{K}_{\text {inv } 2} \Delta \theta(\mathrm{s})+\mathrm{K}_{\text {inv3 }} \Delta \mathrm{V}_{\text {inv }}(\mathrm{s})+\mathrm{K}_{\text {inv }} \Delta \mathrm{V}(\mathrm{s}) \\
& \Delta \mathrm{Q}_{\mathrm{INV}}(\mathrm{s})=\mathrm{K}_{\text {inv } 5} \Delta \delta_{\text {in }}(\mathrm{s})+\mathrm{K}_{\text {inv6 }} \Delta \theta(\mathrm{s})+\mathrm{K}_{\text {inv }} \Delta \mathrm{V}_{\text {in }}(\mathrm{s})+\mathrm{K}_{\text {inv8 }} \Delta \mathrm{V}(\mathrm{s})
\end{aligned}
$$

The parameters/constants $\mathrm{P}_{\text {in }}, \mathrm{V}_{\text {inv }} \angle \delta$ and $\mathrm{X}_{\mathrm{TINV}}$ are input power, inverter voltage and reactance of coupling transformer. $T_{d}$ is system time delay. In case of WES $T_{d}=2.5 \mathrm{~s}$ and for PVS $T_{d}=0.005 \mathrm{~s}$. $K_{\text {inv1 }}, K_{\text {inv2 }}$--- $\mathrm{K}_{\text {inv8 }}$ are constant of the above-mentioned equations, associated with state variables. The block diagram of the inverter with real and reactive power control is shown in Figure 2. The function of the proportional integral controllers is to establish $\Delta \delta$ and $\Delta \mathrm{V}_{\text {inv }}$ of the inverter such that $\Delta \mathrm{P}_{\text {inv }}=\Delta \mathrm{P}_{\text {inv }}$ under steady state conditions. Data pertaining to WES and PVS are given in Table 6 and Table 8.

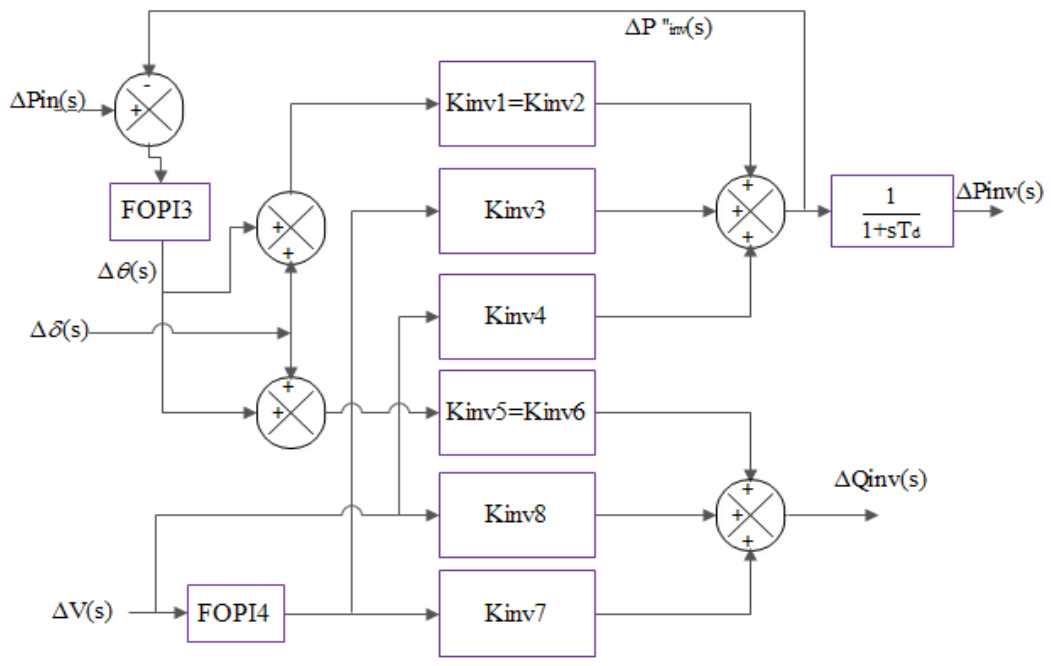

Figure 2. Transfer function model of inverter 


\subsection{Modeling of biogas generator set}

The block diagram of biogas system having electronic speed governor is shown in Figure 3. $\mathrm{T}_{\mathrm{BG}}$ to $\mathrm{T}_{\mathrm{BG} 7}$ are time constant of biogas engine mechanism. Data pertaining to BG1 and BG2 are given in Table 5 and Table 7.

The regulatory valve supplies biogas to the engine. Valve position is regulated by the actuator which depends on signal from the speed governor. The signal is generated in response to frequency and voltage angle change. The change in active power output of the biogas-genset is given by (17) and (18).

$$
\begin{aligned}
& \triangle P B G(s)=\frac{1}{1+s T B G 7} \Delta X V B(s) \\
& \triangle X V B(s)=\frac{(1+s T B G 4)}{s(1+s T B G 5)(1+s T B G 6)} \Delta X A B(s)
\end{aligned}
$$

The regulation in the actuator input signal is governed by the speed governor design and it is given by (19).

$$
\triangle X A B(s)=\frac{(1+s T B G 3)}{s(1+s T B G 1)\left(s^{2} T B G 1 T B G 2\right)} \Delta P A B G(s)
$$

An IEEE type-I excitation control as shown in Figure 4 is considered neglecting saturation. The small deviance in voltage behind transient reactance, $\Delta \mathrm{E}^{\prime} \mathrm{qB}$, is given by (20).

$$
\left(1+\mathrm{sT}_{G B G}\right) \Delta \mathrm{E}^{\prime}{ }_{\mathrm{qBG}}=\left[K_{1 B G} \Delta \mathrm{E}_{\mathrm{fdB}}(\mathrm{s})+K_{2 \mathrm{BG}} \mathrm{K} \Delta \mathrm{V}(\mathrm{s})\right]
$$

For small deviance in system voltage, the reactive power added by the biogas-genset is given by (21).

$$
\Delta Q_{B G}(s)=\left[\mathrm{K}_{3 \mathrm{BG}} \Delta \mathrm{E}_{\mathrm{qB}}^{\prime}(\mathrm{s})+\mathrm{K}_{4 \mathrm{BG}} \Delta \mathrm{V}(\mathrm{s})\right]
$$

Assuming that $\mathrm{SG}$ is operating at constant power factor, the reactive power change due to change in real power is given by (22).

$$
\Delta \mathrm{Q}_{\mathrm{BG}}^{\prime}(\mathrm{s})=\mathrm{K}_{\mathrm{rb}} \Delta \mathrm{P}_{\mathrm{BG}}(\mathrm{s})
$$

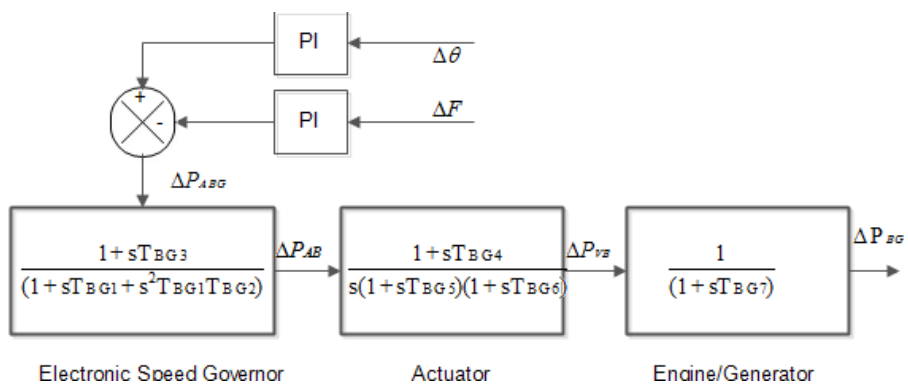

Figure 3. Transfer function model of biogas-genset for real power control

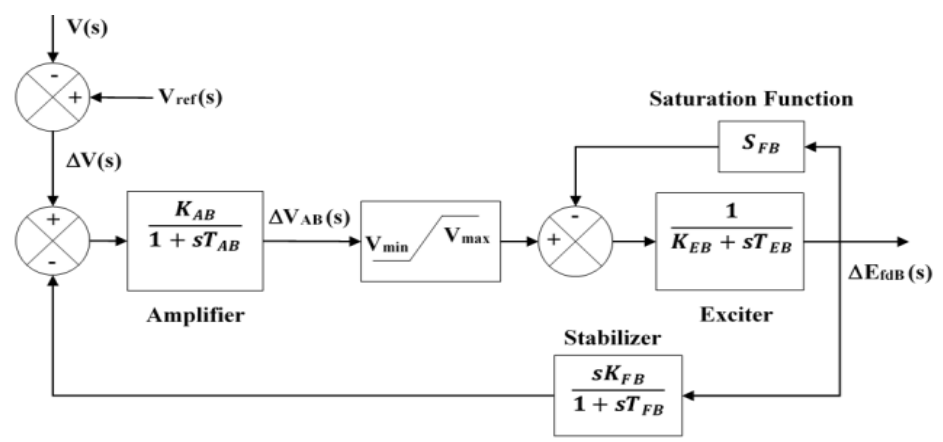

Figure 4. Model of IEEE Type-I excitation control system for biogas-genset 


\subsection{Modeling of main grid}

In a grid connected system, the transformer with the help of online and offline tap changer is used to regulate the secondary winding voltage. Primary voltage of the transformer is considered to be constant. The slight alteration in active and reactive power of the grid can be written in state variables as (23) and (24).

$$
\begin{aligned}
& \Delta P_{G}(s)=K_{1 G} \Delta \theta(s)+K_{2 G} \Delta V(s) \\
& \Delta Q_{G}(s)=K_{3 G} \Delta \theta(s)+K_{4 G} \Delta V(s)
\end{aligned}
$$

The change in system bus voltage angle with change in the system frequency is given by (25).

$$
\Delta \theta=\frac{2 \pi}{s} \Delta F(s)
$$

\subsection{AC network}

Figure 5 shows the model of AC network. The AC interconnection is a low voltage short ariel bunched cable to interconnect the two clusters that we are considering, i.e., MG-1 and MG-2. Transfer function model AC Network in terms of power flow is given in Figure 6. Ps and Qs are sending end active and reactive power and $\mathrm{Pr}$ and $\mathrm{Qr}$ are receiving end active and reactive power. Being a short line, line efficiency is considered $95 \%$ and power at receiving end is $100 \mathrm{~kW}$, therefore, the AC Network have been designed considering line loss of $5 \mathrm{~kW}$. The impedance of the line is given by $\mathrm{Z} \angle \Psi=0.623 \angle 25.55^{\circ}$. Incremental change in power flow due to change in load or change in generation is given by (26), (27), (28), (29), (30), (31), (32) and (33).

$$
\begin{aligned}
& P s=\frac{V_{1}^{2} \operatorname{Cos} \psi-v_{1} v_{2} \operatorname{Cos}\left(\Psi+\delta_{12}\right)}{Z} \\
& Q s=\frac{V_{1}^{2} \operatorname{Sin} \psi-v_{1} v_{2} \operatorname{Sin}\left(\Psi+\delta_{12}\right)}{Z} \\
& \operatorname{Pr}=\frac{v_{1} v_{2} \operatorname{Cos}\left(\Psi+\delta_{12}\right)-V_{1}^{2} \operatorname{Cos} \psi}{Z} \\
& \operatorname{Pr}=\frac{v_{1} v_{2} \operatorname{Sin}\left(\Psi+\delta_{12}\right)-V_{1}^{2} \sin \psi}{Z} \\
& \Delta P S=K 1 a c \Delta V 1+K 2 a c \Delta V 2+K 3 a c \Delta \delta 12 \\
& \Delta Q s=K 4 a c \Delta V 1+K 5 a c \Delta V 2+K 6 a c \Delta \delta 12 \\
& \Delta P r=K 7 a c \Delta V 1+K 8 a c \Delta V 2+K 9 a c \Delta \delta 12 \\
& \Delta Q r=K 10 a c \Delta V 1+K 11 a c \Delta V 2+K 12 a c \Delta \delta 12
\end{aligned}
$$

Where K1ac, K2ac, ---- K12ac are constant of the above-mentioned equations, associated with state variables. The values of the constants are given in Table 2 .

\subsection{Fractional order proportional integral controller}

In this paper, the simulation has been carried out using fractional order proportional integral controller. For FOPI FOMCON toolbox in MATLAB/Simulink is used. The improvement/tuning of control system performance in the time domain is carried out by minimizing error signal $\mathrm{e}(\mathrm{t})$ using integral square error (ISE). The fractional order PI controller transfer function is given by (34).

$$
G(s) \alpha=K p+\frac{K i}{s^{\alpha}}
$$

Where $\alpha$ is non-integer. In case of FOPI three variables i.e. $\mathrm{Kp}, \mathrm{Ki}$ and $\alpha$ need to be tuned instead of two variables in case of conventional PI Controller. The values of $\mathrm{Kp}, \mathrm{Ki}$ and $\alpha$ are given at Table 1. 


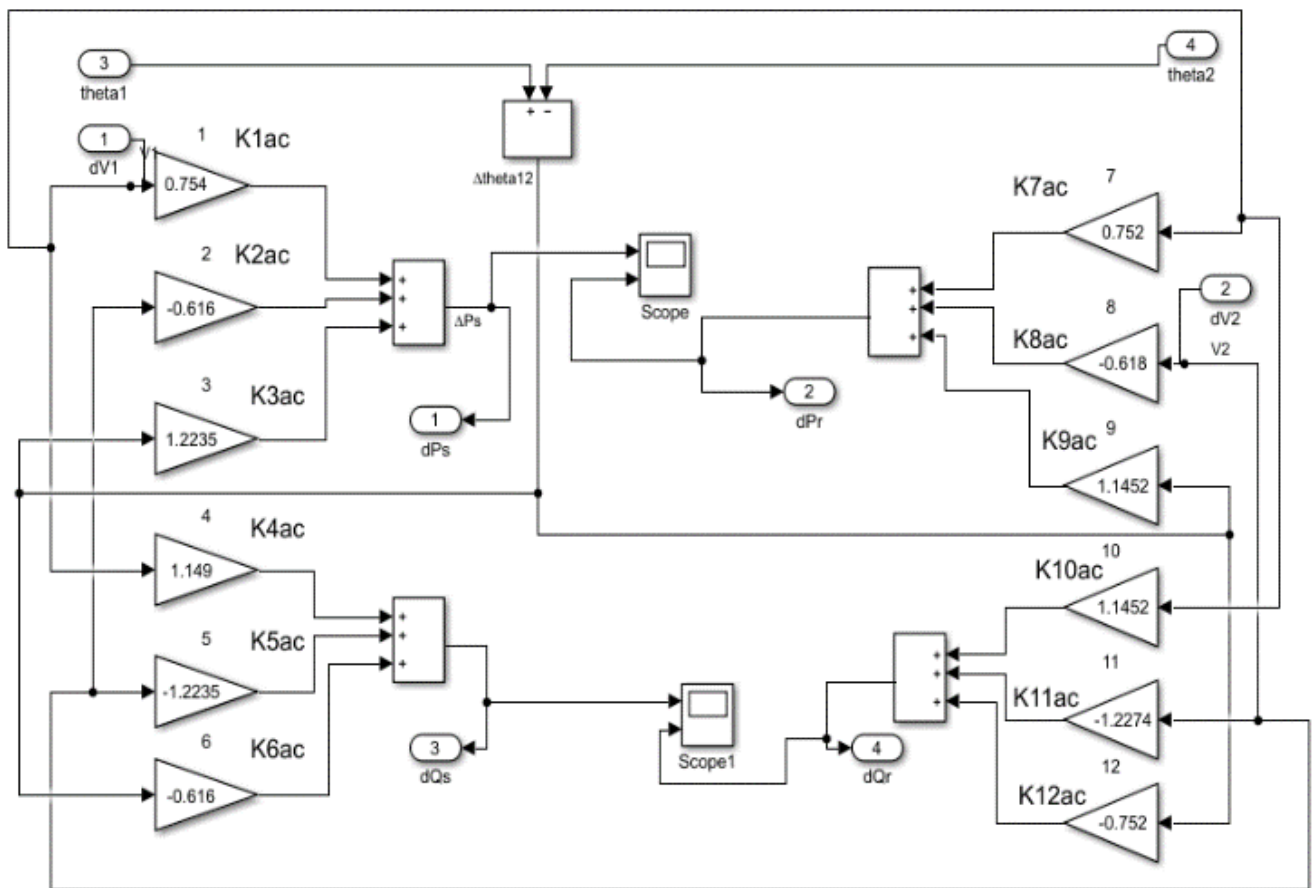

Figure 5. Model of AC network

\section{SYSTEM SIMULATION AND RESULTS}

The transfer function model of the microgrid system MG-1 and MG-2 using PVS-biogas and PVSbiogas-limited grid is shown in Figures 7(a) and (b) respectively. In this paper only one typical example is considered i.e. in both the Clusters MG-1 and MG-2, step load is increased by $1 \%$. Further, it is assumed that input power to WES in MG-1 increases by $1 \%$ and input solar power to PVS decreases by $1 \%$. Figure 7(c) shows dynamic response of the system (MG-1) due to $1 \%$ increase in active and reactive power of load and $1 \%$ increase in wind input power, time (second) versus change in voltage.

In MG-1 due to step increase in load and increase in input wind power by $1 \%$, the wind active and reactive power output increases gradually along with decrease in output of biogas. It takes around $9 \mathrm{~s}$ for output power to reach steady state in MG-1 in Figures 7(d) and (e). This is due to the slow response of wind turbine. However, frequency and voltage angle reach steady state within $5 \mathrm{~s}$ in Figures 7 (a) and (b). The voltage reaches steady state within $60 \mathrm{msec}$ in Figure 7(c). Figures 8(a), (b), (c) shows dynamic response of the system (MG-2) due to $1 \%$ increase in active and reactive power of load and $1 \%$ decrease in solar input power, time (second) versus change in frequency, change in voltage angle and change in voltage.

In MG-2 due to step increase in load by $1 \%$ and decrease in solar power, active power output of PVS inverter decreases immediately in Figure 8(d). To compensate, initially power is drawn from the grid which slowly decreases as the output power from the biogas increases. The steady state of active power is achieved within $5 \mathrm{sec}$. Also, the active power drawing from the grid becomes zero. However, the case of reactive power in MG-2 is different in Figure 8(e). Even though the solar input power decreases the coupling capacitor attached with PVS inverter provides reactive power initially and finally taken up by biogas reaching steady state within 5s. As seen from the graph the frequency, Figures 7(a) and 8(a) and voltage angle, Figures 7(b) and 8(c) settles within $5 \mathrm{sec}$ and voltage, Figures 7(c) and 8(c) settles within 60msec in both the microgrid as anticipated. Further, from the frequency graph of both the microgrid it can be interpreted that frequency oscillation is more in MG-2 as compared to MG-1; this is because of presence WES inertia in MG-1 which supports the system working as shock absorber. Oscillation in active and reactive power PVS and Biogas in MG-2 can be interpreted as system interaction with the grid. Coupling capacitor attached with the inverter provide the reactive power initially through the stored energy therefore, voltage profile is maintained quickly. As desired no extra power is drawn from the grid as well as AC network. From the above, it is opined that controllers are tuned to overcome the small disturbance in the system. 


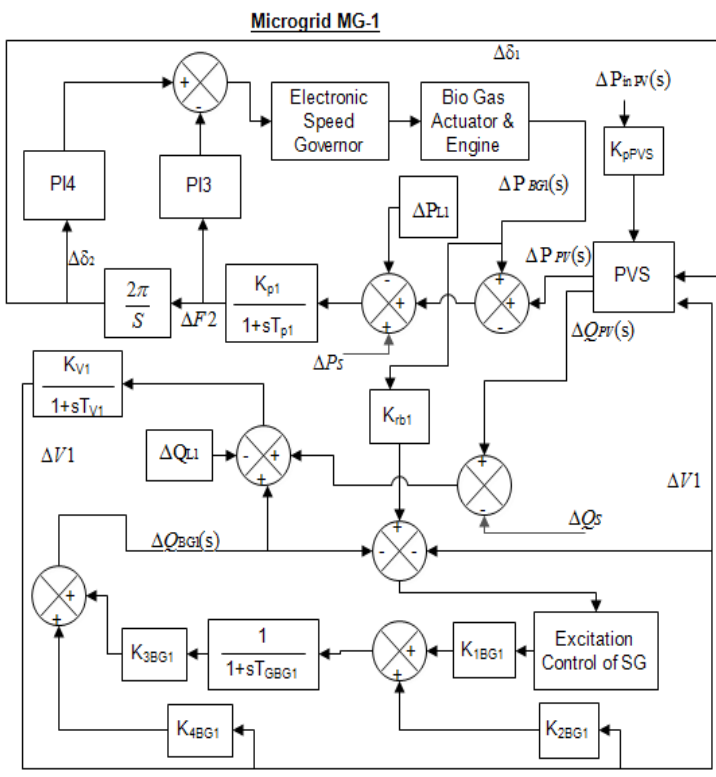

(a)

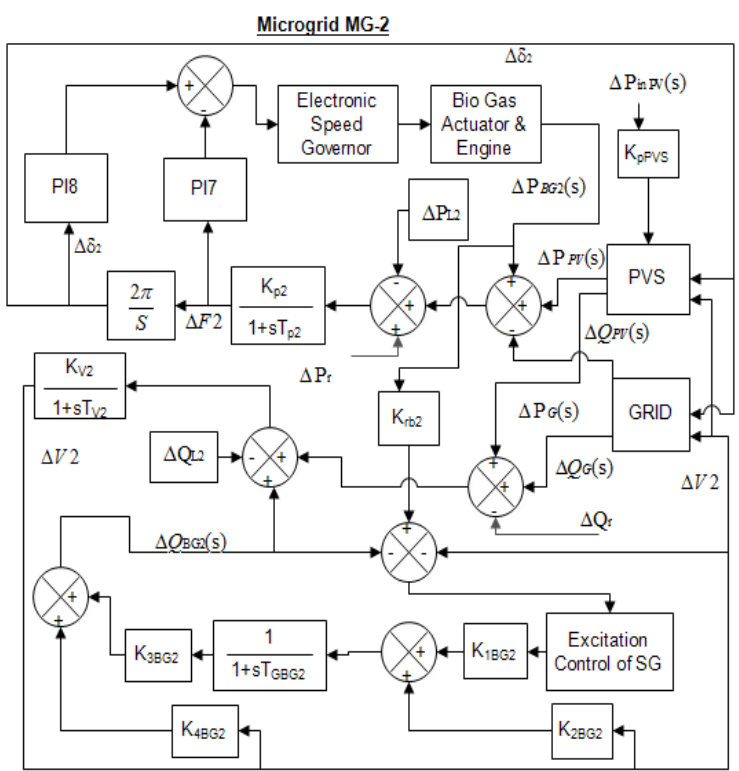

(b)

Figure 6. Transfer function model of: (a) MG-1, (b) MG-2

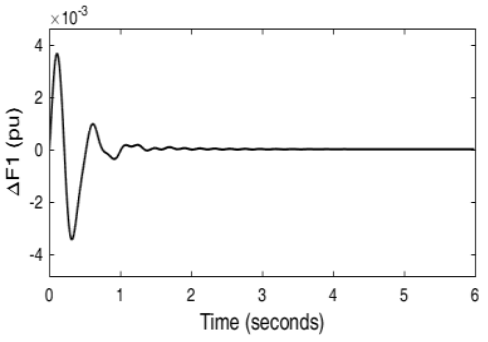

(a)

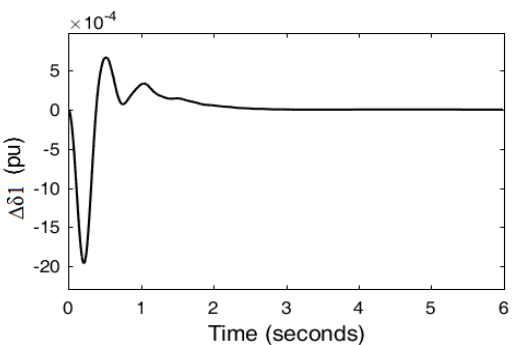

(b)

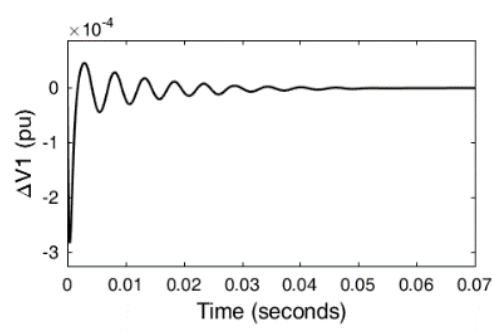

(c)

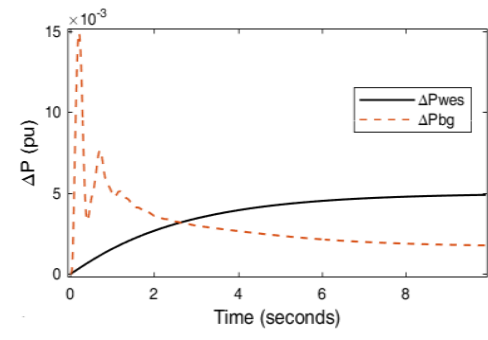

(d)

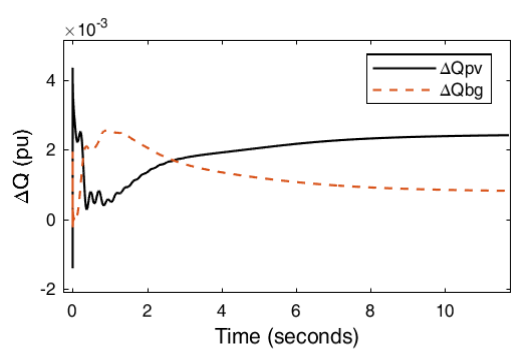

(e)

Figure 7. Dynamic response of the system (MG-1) due to $1 \%$ increase in active and reactive power of load and $1 \%$ increase in wind input power, time (second) versus: (a) Change in frequency, (b) Change in voltage angle, (c) Change in voltage, (d) Change in active power of BG1 and WES, (e) Change in reactive power of BG1 and WES 


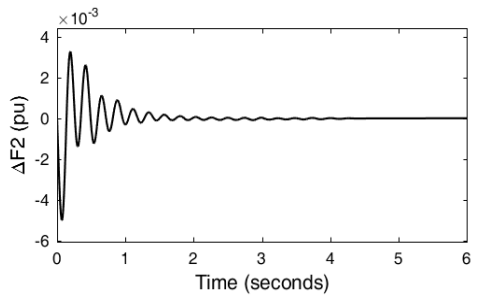

(a)

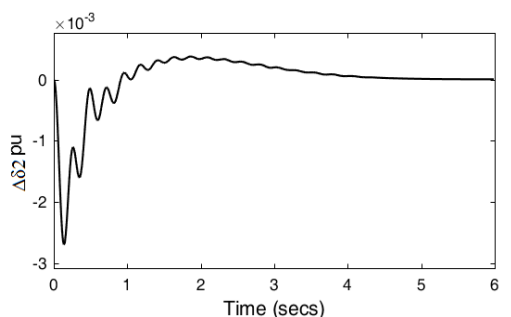

(b)

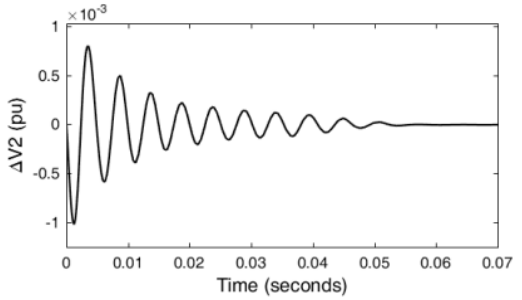

(c)

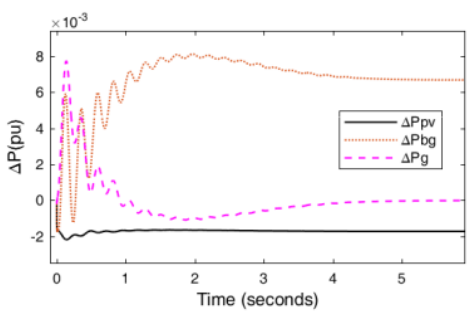

(d)

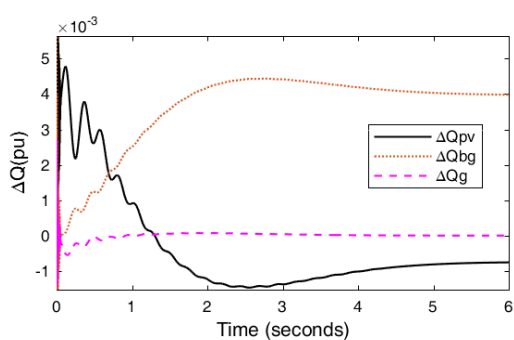

(e)

Figure 8. Dynamic response of the system (MG-2) due to $1 \%$ increase in active and reactive power of load and $1 \%$ decrease in solar input power, time (second) versus: (a) Change in frequency, (b) Change in voltage angle, (c) Change in voltage, (d) Change in active power of BG2, PVS and grid, (e) Change in reactive power of BG2, PVS and grid

\section{CONCLUSION}

Interconnected microgrid have modeled using wind energy system and photovoltaic system accompanied with biogas based system. One of the microgrid is also connected to main grid. The complete system is tested with $1 \%$ step change in input power to renewable energy sources and load. As per the result the system becomes stable i.e. frequency and angle settles within $5 \mathrm{~s}$ and voltage within $60 \mathrm{~ms}$. As desired no extra power is drawn from the main grid as well ac interconnecting line. Each microgrid gets support from its own system to override the disturbance caused by change in load and input power to renewable sources. From the study it can be interpretated that if the individual control of the cluster is achieved then interconnection of microgrids could be solution for valid optimization of resources. The benefit of ineterconnection is that at time contigency the power transfer can get reversed as per the requirement. Also the line supports initially when there is step change in load or input to the generating resouces.

\section{REFERENCES}

[1] Overview of Indian Power Scenario. [Online]. Available: https://powermin.nic.in.

[2] M. Barnes and P. Binduhewa, "Asynchronous interconnection of a microgrid," CIRED Seminar 2008: SmartGrids for Distribution, 2008, pp. 1-4, doi: 10.1049/ic:20080469.

[3] Ji. Hu, Y. Shan, Y. Xu and J. M. Guerrero, "A coordinated control of hybrid ac/dc microgrids with PV-wind-battery under variable generation and load conditions," Electrical Power and Energy Systems, vol. 104, pp. 583-592, 2019, doi: 10.1016/j.ijepes.2018.07.037.

[4] P. C. Loh, D. Li, Y. K. Chai and F. Blaabjerg, "Autonomous operation of hybrid microgrid with AC and DC subgrids," in IEEE Transactions on Power Electronics, vol. 28, no. 5, pp. 2214-2223, May 2013, doi: 10.1109/TPEL.2012.2214792.

[5] J. J. Justo, F. Mwasilu, J. Lee, and J. Jung, "AC-microgrids versus DC-microgrids with distributed energy resources: A review," Renewable and Sustainable Energy Reviews, vol. 24, pp. 387-405, 2013, doi: 10.1016/j.rser.2013.03.067.

[6] Z. Wang and M. Lemmon, "Stability analysis of weak rural electrification microgrids with droop-controlled rotational and electronic distributed generators," 2015 IEEE Power and Energy Society General Meeting, 2015, pp. 1-5, doi: 10.1109/PESGM.2015.7286507.

[7] X. Tang, W. Deng and Z. Qi, "Investigation of the dynamic stability of microgrid," in IEEE Transactions on Power Systems, vol. 29, no. 2, pp. 698-706, March 2014, doi: 10.1109/TPWRS.2013.2285585.

[8] D. K. Yadav, T. S. Bhatti and Ashu Verma, "Study of integrated rural electrification system using wind-biogas based hybrid system and limited grid supply system," International Journal of Renewable Energy Research-IJRER, vol.7, no.1, pp. 2017. 
[9] S. Mishra, R. Sharma and D. Sharma, "Coordinated active power control of wind, solar and diesel generator in a microgrid," IFAC-PapersOnLine, vol. 48, no. 30, pp. 7-12., doi: 2015

[10] S. Shahbazuddin and G. Sridhar, "Automatic reactive power control of an isolated wind-diesel hybrid power system using firefly algorithm," 2017 International Conference on Recent Trends in Electrical, Electronics and Computing Technologies (ICRTEECT), 2017, pp. 93-100, doi: 10.1109/ICRTEECT.2017.32.

[11] P. Sharma, T. S. Bhatti and K. S. S. Ramakrishna, "Performance of a wind-diesel hybrid power system with STATCOM as a reactive power compensator," Smart Grid and Renewable Energy, vol. 1, no. 3, pp. 153-159, 2010, doi: $10.4236 /$ sgre.2010.13020.

[12] R. Bharanikumar, A. C. Yazhini and N. Kumar, "Modelling and simulation of wind turbine driven permanent magnet generator with new MPPT algorithm," Asian Power electronics journal, vol. 4, no. 2, pp. 52-58, 2010.

[13] S. A. Khan, R. K. Rajkumar, R. K. Rajkumar, Aravind C.V, "Performance analysis of 20 Pole 1.5 KW three phase permanent magnet synchronous generator for low speed vertical axis wind turbine," Energy and Power Engineering, vol. 5, no. 4, pp. 423-428, 2013, doi: 10.4236/epe.2013.54B082.

[14] B. Singh, S. S. Murthy and S. Gupta, "Analysis and design of STATCOM-based voltage regulator for self-excited induction generators," in IEEE Transactions on Energy Conversion, vol. 19, no. 4, pp. 783-790, Dec. 2004, doi: 10.1109/TEC.2004.827710.

[15] M. A. G. de Brito, L. Galotto, L. P. Sampaio, G. d. A. e Melo and C. A. Canesin, "Evaluation of the main MPPT techniques for photovoltaic applications," in IEEE Transactions on Industrial Electronics, vol. 60, no. 3, pp. 11561167, March 2013, doi: 10.1109/TIE.2012.2198036.

[16] S. R. Wenham, M. A. Green, M. E. Watt and R. Corkish, "Modeling of solar irrandiance and cells," in Applied Photovoltaics, 2nd ed. Padstow, England: TJ International Ltd, 2007, ch. 5, pp. 75-95.

[17] C. Ghenai and I. Janajreh, "Design of solar-biomass hybrid microgrid system in Sharjah," Energy Procedia, vol. 103, pp. 357-362, 2016, doi: 10.1016/j.egypro.2016.11.299.

[18] R. Nazir, H. D. Laksono, E. P. Waldi, E. Ekaputra and P. Coveria, "Renewable energy sources optimization: A micro-grid model design," Energy Procedia, vol. 52, pp. 316-327, 2014, doi: 10.1016/j.egypro.2014.07.083.

[19] R. Salcedo et al., "Benefits of a nonsynchronous microgrid on dense-load LV secondary networks," in IEEE Transactions on Power Delivery, vol. 31, no. 3, pp. 1076-1084, June 2016, doi: 10.1109/TPWRD.2015.2420594.

[20] A. Ulbig, T. S. Borsche, and G. Andersson, "Analyzing rotational inertia, grid topology and their role for power system stability”, IFAC-PapersOnLine, vol. 48, no. 30, pp. 541-547, 2015, doi: 10.1016/j.ifacol.2015.12.436.

[21] I. Podlubny, "Fractional-order systems and PI/sup /spl lambda//D/sup /spl mu//-controllers," in IEEE Transactions on Automatic Control, vol. 44, no. 1, pp. 208-214, Jan. 1999, doi: 10.1109/9.739144.

[22] K. Åström and T. Hägglund, "PID Controllers: Theory, Design, and Tuning," in 2nd ed. The Instrumentation, Systems, and Automation Society (ISA), 1995.

[23] D. Valerio and J. Sa da Costa, "A review of tuning methods for fractional PIDs," 4th IFAC Workshop on Fractional Differentiation and its Applications, FDA, vol. 10, no. 5, 2010.

[24] F. M.-Bayat, "Rules for selecting the parameters of oustaloup recursive approximation for the simulation of linear feedback systems containing $\mathrm{PI}^{\alpha} \mathrm{D}^{\delta}$ controller," Communications in Nonlinear Science and Numerical Simulation, vol. 17, no. 4, pp. 1852-186, 201210.1016/j.cnsns.2011.08.042.

[25] A. Tepljakov, E. Petlenkov, J. Belikov and J. Finajev, "Fractional-order controller design and digital implementation using FOMCON toolbox for MATLAB," 2013 IEEE Conference on Computer Aided Control System Design (CACSD), 2013, pp. 340-345, doi: 10.1109/CACSD.2013.6663486.

[26] A. Tepljakov, E. Petlenkov and J. Belikov, "FOPID controller tuning for fractional FOPDT plants subject to design specifications in the frequency domain," 2015 European Control Conference (ECC), 2015, pp. 3502-3507, doi: 10.1109/ECC.2015.7331076. 